\title{
Spanish Moth or Convict Caterpillar, Xanthopastis timais (Cramer) (Insecta: Lepidoptera: Noctiuidae) ${ }^{1}$
}

John B. Heppner, Kathryn A. Barbara and Eileen A. Buss ${ }^{2}$

\section{Introduction}

The Spanish moth, Xanthopastis timais

(Cramer), is unmistakable for any other moth in Florida. The larvae are likewise very colorful, and have been called convict caterpillars. The larvae are occasional pests of lilies, mainly in Amaryllidaceae. Spotted larval forms of Spanish moth appear similar to lily borer larvae, Brithys crini (Fabricius) (Godfrey 1972) of Europe and the Old World tropics, but only the banded larval form of the Spanish moth occurs in North America.

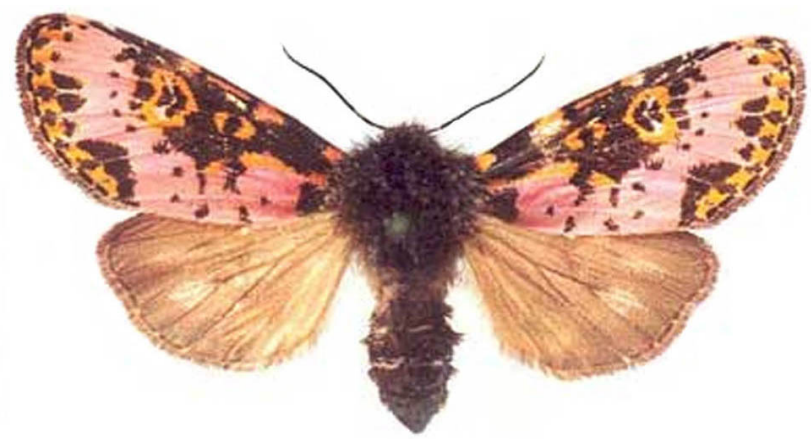

Figure 1. An adult Spanish moth, Xanthopastis timais (Cramer). Credits: Terry DelValle, Extension Agent, Duval Co., FL

\section{Synonymy}

Xanthopastis timais (Cramer)

Xanthopastis amaryllidis Sepp

Xanthopastis heterocampa Guenée

Xanthopastis regnatrix Grote

Xanthopastis antillium Dyar

Xanthopastis moctezuma Dyar

Xanthopastic molinoi Dyar

\section{Distribution}

The Spanish moth, originally described from Surinam, is found throughout lowland areas of South and Central America, and in the Caribbean. The Spanish moth occurs throughout all lowland Neotropical regions of the Caribbean, and as far south as northern Argentina. In North America, the species has a southeastern distribution, from the Carolinas to Texas, but strays northward along the Atlantic Coast as far as coastal New York, and inland

1. This document is EENY-271, one of a series of Featured Creatures from the Entomology and Nematology Department, Florida Cooperative Extension Service, Institute of Food and Agricultural Sciences, University of Florida. Published: June 2002. This document is also available on Featured Creatures Website at http://creatures.ifas.ufl.edu. Please visit the EDIS Website at http://edis.ifas.ufl.edu.

2. John B. Heppner, Florida Department of Agriculture, Division of Plant Industry, Gainesville; Kathryn A. Barbara and Eileen A. Buss, Entomology and Nematology Department, Insitute of Food and Agricultural Sciences, University of Florida, Gainesville, FL.

The Institute of Food and Agricultural Sciences (IFAS) is an Equal Employment Opportunity - Affirmative Action Employer authorized to provide research, educational information and other services only to individuals and institutions that function without regard to race, creed, color, religion, age, disability, sex, sexual orientation, marital status, national origin, political opinions or affiliations. For information on obtaining other extension publications, contact your county Cooperative Extension Service office. Florida Cooperative Extension Service / Institute of Food and Agricultural Sciences / University of Florida / Larry R. Arrington, Interim Dean 
as far north as Kentucky and Arkansas. It occurs in all of Florida (Slosson 1894); see also Dyar (1901, 1902), Frost (1964), and Kimball (1965).

\section{Description}

Adult Spanish moths are relatively uniform in coloration throughout their range from North America to the Neotropics. Adults have rosy-pink and black forewings, spotted with orange along the wing veins, with a black body and gray hindwings. Some varieties have more white than pink on the forewings. Larvae are variable in Latin America, but in Florida are black with cream-white or yellow-white bands and orange head, prolegs, and posterior end. In addition to the whitish band, each body segment also has a dorsal and a lateral patch of cream-white near each band. The head and posterior end each have two eye-like black spots, making the posterior end appear much like the head. Variation in the Neotropics is mostly in the amount of orange on the head and posterior, and with the yellow-white body banding more as spots than bands. Larvae are up to $5 \mathrm{~cm}$ long and feed gregariously on leaves, bulbs and rhizomes of the host plants. Numbers of larvae can damage lily leaves in a short time. The pupa of the Spanish moth is typical for noctuid moths and almost black in color. Eggs are rounded (somewhat flattened) and yellowish, otherwise typical for noctuid moths (Dyar 1901).

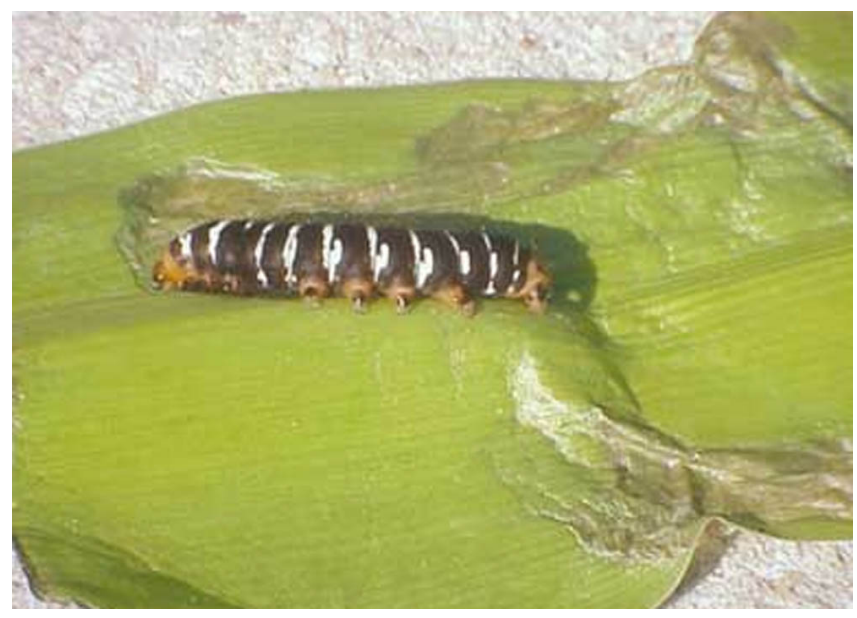

Figure 2. Spanish moth larva (convict caterpillar), Xanthopastis timais (Cramer), feeding on amaryllis. Credits: Terry DelValle, Extension Agent, Duval Co., FL

\section{Life Cycle}

In Florida, Spanish moth adults are active from January to early June, and September to December, but may have nearly continuous generations in the southernmost areas of the state and possibly also in greenhouse production. Females lay several hundred eggs grouped in clusters (Bourquin 1935), usually on the lower leaf surfaces. Larvae pupate in loose soil. Larvae have six instars (Bourquin 1935). Larval ecolsion takes about eight days under optimal conditions, followed by 17 days of larval feeding. The pupal stage lasts about 19 days. Adults usually live about eight to 10 days, including two to three days for adult flight and mating. A total generation time of seven to eight weeks allows up to six generations per year.

\section{Host Plants}

Spanish moth larvae mainly feed on spider lilies and other Amaryllidaceae, plus Iridaceae and Liliaceae (Tietz 1972). Reports of Ficus (Moraceae) and Hibiscus (Malvaceae) as hosts are probably erroneous, but Xanthosoma and Zantedeschia (both Araceae) are rare alternate hosts. Incidental records include Cocoloba uvifera (Polygonaceae) (DPI record) and Polianthes tuberosa (Agavaceae) (Pirone 1970); also Lactuca sp. (Compositae) (Covell 1984) in lab rearings. Host plant records in Amaryllidaceae include amaryllis, Clivia, Cooperia, Eucharis, Haemanthus, Hippeastrum, Hymenocallis, Narcissus, Pancratium, Polianthes, and Zephyranthes; in Iridaceae, Iris; and in Liliaceae, Crinum, Leucojum and Lilium.

\section{Damage}

Spanish moth larvae cause damage by chewing gregariously on leaves, bulbs, and rhizomes of the host plants. Economic damage to lilies by Spanish moth has been noted by Biezanko and Guerra (1975), Bourquin (1935), Bruner et al. (1975), D'Angelo (1941), Figeiredo and Pereira (1944), Gundlach (1881), Martorell (1976), Monte (1932, 1934), Pirone (1970), and Wolcott $(1936,1951)$. 


\section{Management}

\section{Sampling}

Periodically examine leaves for Spanish moth caterpillars. Direct observation of larvae on the plant during the early stages of growth in the spring is the best sampling option due to the plant's small size. Adult moth populations can be sampled using a blacklight. Once moths are detected, searching for eggs and larvae is the next step.

\section{Insecticides}

Larvae can be sprayed with a bacterial spray, or more immediate results can be obtained from the application of various pesticides. In French Guiana, an ectoparasitic nematode has been reported on larvae of Spanish moth and other noctuid moths (Rogers et al. 1990). Brunner et al. (1975) note a Tachinid fly parasitoid.

For more information see: Insect Management Guide for Landscape Plants (http://edis.ifas.ufl.edu/IG013).

\section{Selected References}

Biezanko CM, Guerra M de S. 1975. Contribução ao estudo de Xanthopastis timais Stoll, 1782 importante praga das amarilidaceas (Lepidoptera, Heterocera, Noctuidae). Arquivos do Museu Nacional 54: 267-272.

Bourquin F. 1935. Metamorfosis de Xanthopastis timais Cr. (Lep. Noct.). Revista de la Sociedad Entomologica de Argentina 7: 195-201.

Bruner SC, Scaramuzza LC, Otero AR. 1975. Catalogo de los Insectos que Atacan a las Plantas Economicas de Cuba. 2nd ed. Academia de Ciencias de Cuba, Inst. de Zoología, Havana. 399 p.

Covell Jr CV. 1984. Field Guide to the Moths of Eastern North America. Houghton-Mifflin, Boston. $496 \mathrm{p}$.

D'Angelo WA. 1941. Mariposa dañina para ciertas plantas de jardín Xanthopastis timais, Cram. Almanaque de Ministerio de Agricultura Argentinas 16: 169-172.
Dyar HG. 1901. Notes on the winter Lepidoptera of Lake Worth, Florida. Proceedings of the Entomological Society of Washington 4: 446-485

Dyar HG. 1902. The larva of Euthanisotia timais Cram. Journal of the New York Entomological Society 10: 125-126.

Figueiredo Jr ER de, Pereira HF. 1944. Notas sôbre Xanthopastis timais (Cram.) (Lep. Noct.), praga das amarilidáceas. Arquivos do Instituto de Biologica (São Paulo) 15: 289-298.

Frost SW. 1964. Insects taken in light traps at the Archbold Biological Station, Highlands County, Florida. HYPERLINK "Biezanko CM, Guerra M de S. 1975. Contribução ao estudo de Xanthopastis timais Stoll, 1782 importante praga das amarilidaceas (Lepidoptera, Heterocera, Noctuidae). Arquivos do Museu Nacional 54: 267-272.

Godfrey GL. 1972. A review and reclassification of larvae of the subfamily Hadeninae (Lepidoptera, Noctuidae) of America north of Mexico. U.S. Department of Agriculture Technical Bulletin 1450. $265 \mathrm{p}$.

Gundlach J. 1881. Contribución á la Entomología Cubana. Havana. 445 p.

Kimball CP. 1965. The Lepidoptera of Florida: an annotated checklist. In Arthropods of Florida and Neighboring Land Areas. Vol. 1. Florida Department of Agriculture and Consumer Services, Division of Plant Industry, Gainesville. 363 p., 26pl.

Martorell LF. 1976. Annotated Food Plant Catalog of the Insects of Puerto Rico. Agricultural Experiment Station, University of Puerto Rico, Rio Piedras. 303 p.

Monte O. 1932. Notas biologicas sobre o lepidoptero noctuido Xanthopastis timais Cram. O Campo (Rio de Janeiro) 3: 41-42.

Monte O. 1934. Borboletas que vivem em plantas cultivadas. Boletim de Agric. Zootechnia e Veterinária (Ser. Agricola) 7: 111-112.

Pirone PP. 1970. Diseases and Pests of Ornamental Plants. 4th ed. Ronald Press, New York, $546 \mathrm{p}$. 
Rogers CE, Marti OG, Simmons AM, Silvain JF. 1990. Host range of Noctuidonema guyanense (Nematoda: Aphelenchoididae): an ectoparasite of moths in French Guiana. Environmental Entomology 19: 795-798.

Slosson AT. 1894. Florida field notes. Journal of the New York Entomological Society 2: 106- 107.

Tietz hM. 1972. An Index to the Described Life Histories, Early Stages and Hosts of the Macrolepidoptera of the Continental United States and Canada. Allyn Museum of Entomology, Sarasota. 2 v.

Wolcott GN. 1936. Insectae Borinquenses- a revised annotated checklist of the insects of Puerto Rico. Journal of Agriculture, University of Puerto Rico 20: 1-600.

Wolcott GN. 1951. The insects of Puerto Rico. Journal of Agriculture, University of Puerto Rico 32: 1-975. 